\title{
Fine-scale Vertical Movements and Behavior of Immature Skipjack Tuna (Katsuwonus pelamis) off Eastern Taiwan
}

Wei-Chuan Chiang

Eastern Marine Biology Research Center, Fisheries Research Institute, Taiwan, wcchiang@mail.tfrin.gov.tw

Takayuki Matsumoto

National Research Institute of Far Seas Fisheries, Japan Fisheries Research and Education Agency, Shizuoka, Japan

Shian-Jhong Lin

Eastern Marine Biology Research Center, Fisheries Research Institute, Taiwan

Qi-Xuan Chang

Eastern Marine Biology Research Center, Fisheries Research Institute, Taiwan

Michael K. Musyl

Pelagic Research Group LLC, USA

See next page for additional authors

Follow this and additional works at: https://jmstt.ntou.edu.tw/journal

Part of the Fresh Water Studies Commons, Marine Biology Commons, Ocean Engineering Commons, Oceanography Commons, and the Other Oceanography and Atmospheric Sciences and Meteorology Commons

\section{Recommended Citation}

Chiang, Wei-Chuan; Matsumoto, Takayuki; Lin, Shian-Jhong; Chang, Qi-Xuan; Musyl, Michael K.; Ho, Yuan-Shing; and Ohta, Fumio (2021) "Fine-scale Vertical Movements and Behavior of Immature Skipjack Tuna (Katsuwonus pelamis) off Eastern Taiwan," Journal of Marine Science and Technology. Vol. 29: Iss. 2, Article 12.

DOI: 10.51400/2709-6998.1082

Available at: https://jmstt.ntou.edu.tw/journal/vol29/iss2/12

This Research Article is brought to you for free and open access by Journal of Marine Science and Technology. It has been accepted for inclusion in Journal of Marine Science and Technology by an authorized editor of Journal of Marine Science and Technology. 


\section{Fine-scale Vertical Movements and Behavior of Immature Skipjack Tuna}

(Katsuwonus pelamis) off Eastern Taiwan

\section{Authors}

Wei-Chuan Chiang, Takayuki Matsumoto, Shian-Jhong Lin, Qi-Xuan Chang, Michael K. Musyl, Yuan-Shing Ho, and Fumio Ohta 

Eastern Taiwan

\author{
Wei-Chuan Chiang ${ }^{a, *}$, Takayuki Matsumoto ${ }^{b}$, Shian-Jhong Lin ${ }^{a, c}$, Qi-Xuan Chang ${ }^{a}$, \\ Michael K. Musyl ${ }^{\mathrm{a}}$, Yuan-Shing Ho ${ }^{a}$, Fumio Ohta ${ }^{\mathrm{e}}$ \\ ${ }^{\text {a }}$ Eastern Marine Biology Research Center, Fisheries Research Institute, Taiwan \\ ${ }^{b}$ National Research Institute of Far Seas Fisheries, Japan Fisheries Research and Education Agency, Shizuoka, Japan \\ ${ }^{\mathrm{c}}$ Department of Environmental Biology and Fishery Science, National Taiwan Ocean University, Keelung, Taiwan \\ d Pelagic Research Group LLC, USA \\ e Ajinomoto Co., Inc., Chuo-ku, Tokyo, Japan
}

\begin{abstract}
Skipjack tuna are globally distributed in tropical and temperate seas but little is known about their fine-scale diving patterns and how fish size and (or) maturity influences patterns off eastern Taiwan. A total of 211 immature skipjack $(36-47 \mathrm{FL} \mathrm{cm})$ in the study were caught by trolling near subsurface fish aggregating devices (FADs) near Green Island (southeastern Taiwan) and were tagged with Lotek LAT-2910 archival tags. The low rate of recovery (2.4\%) suggests a high post-release mortality but this low rate could also be consistent with large population sizes, dispersal, tag loss or uncooperative fishers. Five individuals were recovered near the release locations and tags provided data archiving 11-31 days-at-liberty. Tagged skipjack tuna dove deeper during daytime than at nighttime $(\mathrm{p}<0.001)$ and displayed repetitive bounce-diving behavior to depths between $50-310 \mathrm{~m}$ during daytime. During the deepest dives, ambient temperatures reached a low of $13.1^{\circ} \mathrm{C}$ with peritoneal temperatures at $17.0^{\circ} \mathrm{C}$. The vertical movements and habitat preferences reported herein this study are the first fishery-independent observations on immature skipjack and provide evidence of the degree of ecological niche and fisheries interactions of skipjack tuna in eastern Taiwan.
\end{abstract}

Keywords: Archival tag, Diel oscillation, Ecological niche, Fish aggregating devices, Habitat preference

\section{Introduction}

$\mathrm{S}$ kipjack tuna is a highly migratory pelagic species with a global distribution from equatorial to temperate zones of the world's oceans [19]. The distribution of skipjack is influenced by the $29^{\circ} \mathrm{C}$ sea surface temperature (SST) isotherm and by strength of the El Niño-Southern Oscillation [14]. Biotic and abiotic factors also shape the habitat utilization of skipjack. Physiological tolerances of temperature $[9,1]$ and oxygen [9] have indicated that skipjack inhabit predominantly the mixed-layer but make occasional brief dives below the thermocline. In turn, temperature and dissolved oxygen tolerances have been used in numerical modelling approaches as an accessibility coefficient to estimate skipjack foraging habitat $[15,26]$.

Archival tagging studies in the western Pacific Ocean indicated that skipjack thermal habitat was defined by temperatures ranging from $18.8{ }^{\circ} \mathrm{C}$ to $28.2{ }^{\circ} \mathrm{C}$ with the $18{ }^{\circ} \mathrm{C}$ isotherm as an approximate boundary for the lowest limit [13]. Advances in electronic tagging have provided fishery- 


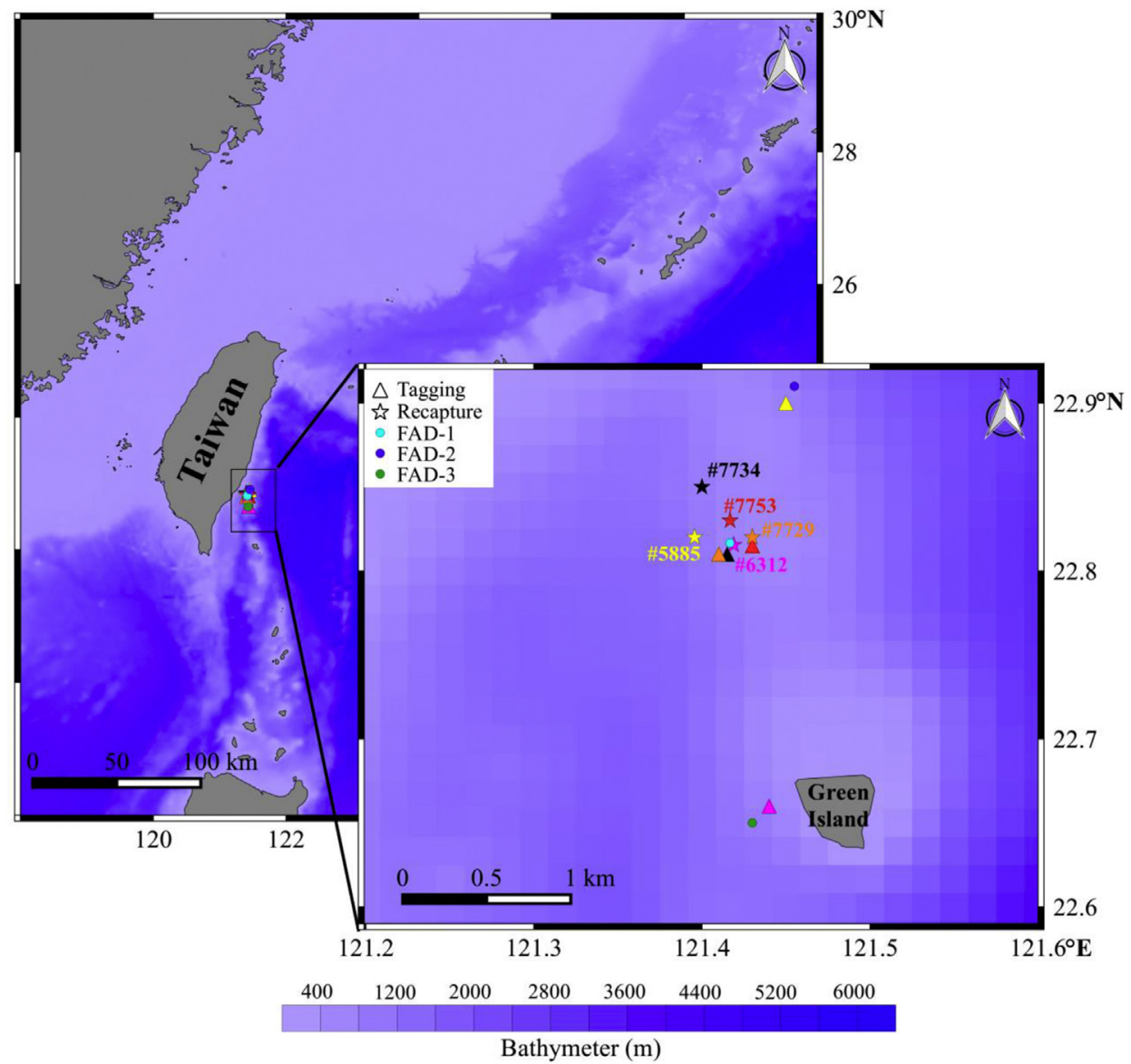

Fig. 1. Location of FADs off eastern Taiwan (near Green Island) and 5 skipjack tuna (\#5885, 6312, 7753, 7734 and 7729) tagged (triangle shape) and recaptured area (star shape).

independent investigations on potential foraging and spawning habitats of similar tuna species $[22,25,17,2,3]$ as well as new insights into the ecology and migration of skipjack [24]. Studies have been conducted on the behavior of skipjack using ultrasonic telemetry $[9,11,18,30]$.

Fish aggregating devices (FADs) have been used by fisheries to attract and aggregate many marine species, including tuna and non-tuna species, because of the natural tendency of species to follow drifting objects $[16,9,21]$. Using ultrasonic tags, [30] reported that juvenile yellowfin tuna and skipjack tuna were the main species occupying FADs in southwestern Taiwan. Other studies have reported on the behavior of adult skipjack associated with anchored or drifting FADs [24]. The objectives of this study were to elucidate the vertical movement patterns and behavior of immature skipjack associated with subsurface FADs in eastern Taiwan.

\section{Material and Methods}

\subsection{Archival tag deployments}

Skipjack tuna were captured by trolling methods (pink feathers and swimming ballyhoo) around three anchored FADs during the early morning in

Table 1. Tagging details for skipjack tuna implanted with archival tags that were recovered.

\begin{tabular}{|c|c|c|c|c|c|c|c|c|c|c|}
\hline \multirow[t]{2}{*}{$\begin{array}{l}\text { Survey } \\
\text { year }\end{array}$} & \multirow[t]{2}{*}{$\begin{array}{l}\text { Archival } \\
\text { tag \#ID }\end{array}$} & \multirow[t]{2}{*}{ Deployment date } & \multicolumn{2}{|c|}{$\begin{array}{l}\text { Deployment } \\
\text { location }\end{array}$} & \multirow[t]{2}{*}{$\begin{array}{l}\text { Fork length at } \\
\text { release }(\mathrm{cm})\end{array}$} & \multirow[t]{2}{*}{ Recapture date } & \multicolumn{2}{|c|}{$\begin{array}{l}\text { Recapture } \\
\text { location }\end{array}$} & \multirow[t]{2}{*}{$\begin{array}{l}\text { Recapture fork } \\
\text { length }(\mathrm{cm})\end{array}$} & \multirow[t]{2}{*}{$\begin{array}{l}\text { Days-at } \\
\text { liberty }\end{array}$} \\
\hline & & & Lat $(\mathrm{N})$ & Lon $(E)$ & & & Lat $(\mathrm{N})$ & Lon $(E)$ & & \\
\hline 2018 & 5885 & 16 December 2018 & 22.90 & 121.45 & 44 & 15 January 2019 & 22.82 & 121.40 & 45 & 31 \\
\hline 2019 & 6312 & 14 March 2019 & 22.66 & 121.44 & 44 & 8 April 2019 & 22.82 & 121.42 & 47 & 26 \\
\hline 2019 & 7753 & 16 December 2019 & 22.82 & 121.28 & 41 & 26 December 2019 & 22.83 & 121.41 & 45 & 11 \\
\hline 2019 & 7734 & 11 December 2019 & 22.81 & 121.42 & 41 & 23 December 2019 & 22.85 & 121.40 & 45 & 13 \\
\hline 2019 & 7729 & 10 December 2019 & 22.81 & 121.41 & 43 & 2 January 2020 & 22.82 & 121.43 & 44 & 23 \\
\hline
\end{tabular}




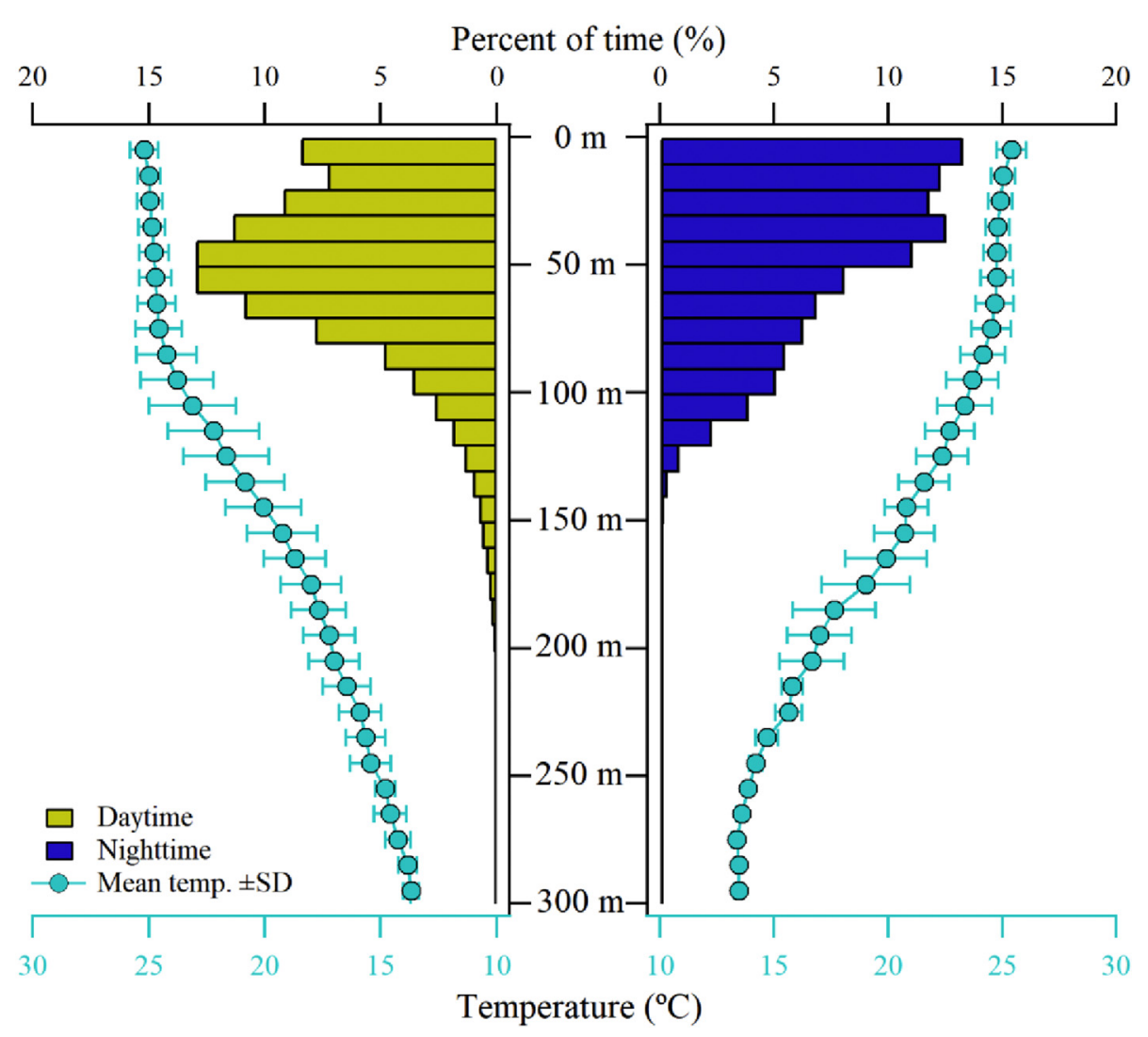

Fig. 2. Frequency distribution of the swimming depth (bar) and vertical profile of mean ambient water temperature (solid line and circle markers) and standard deviation (error bar) for five tagged skipjacks in the daytime (yellow bar) and nighttime (blue bar).

southeastern Taiwan (Table 1, Fig. 1). Each captured skipjack was lifted onto a padded wooden cradle and placed ventral side up to remove the hook. Fish in excellent condition (vigorous with no bleeding or serious injury) were selected for tag deployment. Archival tags ( $24 \times 8.2 \mathrm{~mm}$, weight $2.9 \mathrm{~g})$ used in this study were model LAT-2910 (Lotek Wireless, Newmarket, ON, Canada). Tags were programmed to record time-series of external and internal temperatures, depth and light intensity acquired every $30 \mathrm{~s}$ with an $8 \mathrm{MB}$ of onboard memory. The maximum depth rating was $2,000 \mathrm{~m}$ (resolution of $0.05 \%$, accuracy of $\pm 1 \%$ ) and the temperature range was from $-5^{\circ}$ to $45^{\circ} \mathrm{C}$ (resolution of $0.2^{\circ} \mathrm{C}$, accuracy of $0.05^{\circ} \mathrm{C}$ )

The tag was inserted into the abdominal cavity by making a small incision $(\sim 1.5 \mathrm{~cm})$ by scalpel and the wound was sutured closed with leukoclips ${ }^{\circledR}$ (Leukoclip Stapler SD Handle, AMA PRODUCTS, Australia). Conventional plastic dart tags (PDA tag: length $14 \mathrm{~cm}$, diameter $1.7 \mathrm{~mm}$; Hallprint Pty Ltd., Hindmarsh Valley, South Australia, Australia) were attached near the base of the second dorsal fin to aid in tag recovery or if the archival tag was expelled.
Tagging procedures were completed within $\sim 60 \mathrm{~s}$ and tagged fish were immediately released near the FADs (Fig. 1, Table 1). A total of 724 individuals [fork length (FL) $36-47 \mathrm{~cm}$ ] were released (211 conducted with archival tags) between December 2017 and March 2020 (Table S1 in Supplementary Material). Information posters were displayed at fish markets on how to report tag recoveries and receive rewards.

\subsection{Data analysis}

Time-series of depth and temperature were downloaded using proprietary software provided by Lotek Wireless. Archived time series for pressure (depth) and temperature were categorized into daytime and nighttime periods by calculating times of local sunrise and sunset time (http://aa.usno. navy.mil/). The behavior for each day at-liberty was classified as associated or unassociated with floating objects, on the basis of behavioral characteristics from ultrasonic telemetry observations of skipjack tuna associated with floating objects [23]. Moreover, W-shaped vertical movement patterns during the day were characterized as non- 
associative behavior with floating objects where deep descents were followed by upward excursions into the uniform-temperature surface layer [20]. Ambient light data from recaptured tags were downloaded and the daily position of each skipjack tuna was estimated using the Lat Viewer Studio software, version 2.9.36 (Lotek Wireless. Inc.).

To further explore daytime and nighttime differences, we used one-sample Kolmogorov-Smirnov tests to compare distributions of ambient temperature and depth data to that of a normal distribution and all were non-normally distributed. As a result, we used non-parametric two-sample Kolmogorov-Smirnov and Mann-Whitney W-tests to compare differences in medians between daytime and nighttime data for depth and temperature distributions and Kruskal-Wallis non-parametric ANOVAs to compare across tags [33]. Time-atdepth and time-at-temperature data were aggregated into $20-\mathrm{m}$ and $1{ }^{\circ} \mathrm{C}$ bins, respectively. These data were subsequently expressed as a fraction of the total time of observation for skipjack tuna. The $P$ $<0.05$ level was taken to indicate statistical significance.

\section{Results}

Five skipjack (41-44 cm FL at release) were recovered near FADs and provided data archiving 11-31 days-at-liberty for a total of 104 days of data in aggregate (Fig. 1, Table 1). The release and recapture locations around FADs were within 0.5 to 1.5 km (Fig. 1). Two skipjack tuna were recaptured after only 11 (\#7753) and 13 days (\#7734) after release (Table 1) by trolling with lures and indicated the released skipjack resumed normal feeding activities after surgical implantation of the archival tags.

\subsection{Vertical distribution}

For all recovered tags, the mean daytime depth was $55.2 \mathrm{~m}( \pm 36.9 \mathrm{SD}$, range 0 to $310.6 \mathrm{~m})$, ambient temperature was $24.1{ }^{\circ} \mathrm{C}( \pm 1.6 \mathrm{SD}$, range 13.2 to $28.3^{\circ} \mathrm{C}$ ) and peritoneal cavity temperature was 24.9 ${ }^{\circ} \mathrm{C}\left( \pm 1.0 \mathrm{SD}\right.$, range 17.0 to $\left.28.2{ }^{\circ} \mathrm{C}\right)$. At nighttime, mean depth was $46.1 \mathrm{~m}( \pm 32.6 \mathrm{SD}$, range 0 to 301.0 $\mathrm{m})$, ambient temperature was $24.7{ }^{\circ} \mathrm{C}( \pm 1.1 \mathrm{SD}$, range 13.1 to $27.0{ }^{\circ} \mathrm{C}$ ), and peritoneal cavity temperature was $25.0^{\circ} \mathrm{C}\left( \pm 0.9 \mathrm{SD}\right.$, range 18.5 to $\left.27.3^{\circ} \mathrm{C}\right)$ (Table 2). The recovered data show that skipjack spend the majority of their time in the uniform surface-temperature layer between 24 to $28^{\circ} \mathrm{C}$ (Fig. S1) but skipjack \#6312 occupied significant deeper depths than the other tagged skipjack (KruskalWallis non-parametric ANOVA, $P<0.005)$. Skipjack \#7734 and \#7729 were released on consecutive days showed similar vertical movement patterns (Fig. S1) and might be travelling in the same schools around FADs.

\subsection{Diel oscillation}

Daytime and nighttime depths indicated significantly different diel patterns (Fig. 2, S2) with all possible pairwise Kolmogorov-Smirnov and Mann-Whitney $\mathrm{W}$-tests tests significantly different at $P<0.001$. In daytime, tagged skipjack stayed mostly from the surface to $80 \mathrm{~m}$ and at nighttime from the surface to $60 \mathrm{~m}$ at ambient temperatures from 24.5 to $26.5{ }^{\circ} \mathrm{C}$ (Fig. 3).

\subsection{Diving behavior}

All skipjack displayed characteristic W-shaped vertical movement patterns and exhibited repetitive bounce diving more pronounced during daytime (Fig. S3). A 2-day portion of the time series is presented for \#5585 where the fish displayed dissimilar diel movement patterns (Fig. 4) presumably when unassociated with the FAD (Fig. 4, panel A) and primarily surface activity when associated with the FAD (Fig. 4 panel B).

Table 2 shows daily maximum temperature (SST), minimum temperature and maximum depth experienced by tagged skipjack. The $\Delta$ SST analysis

Table 2. Summary of depth, ambient temperature and peritoneal cavity temperature obtained for archival tags deployments on skipjack tuna. Minimum, maximum and mean are provided where SD is the standard deviation.

\begin{tabular}{|c|c|c|c|c|c|c|}
\hline \multirow[t]{2}{*}{$\begin{array}{l}\text { Archival } \\
\text { tag \#ID }\end{array}$} & \multicolumn{2}{|c|}{$\begin{array}{l}\text { Depth }(\mathrm{m}) \\
\text { Min.-max. }(\text { mean } \pm \text { SD) }\end{array}$} & \multicolumn{2}{|c|}{$\begin{array}{l}\text { Ambient temp. }\left({ }^{\circ} \mathrm{C}\right) \\
\text { Min.-max. (mean } \pm \text { SD) }\end{array}$} & \multicolumn{2}{|c|}{$\begin{array}{l}\text { Peritoneal cavity temp. }\left({ }^{\circ} \mathrm{C}\right) \\
\text { Min.-max. (mean } \pm \text { SD) }\end{array}$} \\
\hline & Daytime & Nighttime & Day & Night & Day & Night \\
\hline \#5885 & $0-223.944 .4 \pm 31.2$ & $0-271.429 .4 \pm 26.9$ & $14.8-26.924 .5 \pm 1.7$ & $13.1-27.025 \pm 0.8$ & $16.9-28.825 .2 \pm 1.0$ & $19.0-27.325 .4 \pm 0.6$ \\
\hline \#6312 & $0-310.686 .7 \pm 43.2$ & $0-301.073 .2 \pm 35.3$ & $13.2-28.324 .0 \pm 2.5$ & $13.3-26.824 .4 \pm 1.6$ & $18.8-27.624 .7 \pm 1.5$ & $18.5-27.124 .8 \pm 1.4$ \\
\hline \#7753 & $0-205.840 .3 \pm 21.8$ & $0-105.831 .4 \pm 13.2$ & $14.2-26.124 .5 \pm 0.8$ & $20.9-26.124 .6 \pm 0.4$ & $19.9-26.424 .7 \pm 0.7$ & $23.5-26.424 .8 \pm 0.4$ \\
\hline \#7734 & $0-167.445 .8 \pm 19.0$ & $0-136.438 .5 \pm 23.8$ & $17.6-25.524 .4 \pm 0.4$ & $21.3-25.424 .5 \pm 0.4$ & $21.4-26.124 .7 \pm 0.3$ & $23.2-25.424 .7 \pm 0.3$ \\
\hline \#7729 & $0-199.448 .2 \pm 25.2$ & $0-181.450 \pm 25.6$ & $14.4-26.124 .5 \pm 0.8$ & $21.3-25.424 .5 \pm 0.4$ & $20.1-27.025 .0 \pm 0.6$ & $22.5-26.424 .8 \pm 0.6$ \\
\hline Total & $0-310.655 .2 \pm 36.9$ & $0-301.046 .1 \pm 32.6$ & $13.2-28.324 .4 \pm 1.6$ & $13.1-27.024 .7 \pm 1.1$ & $17.0-28.224 .9 \pm 1$ & $18.5-27.325 .0 \pm 0.9$ \\
\hline
\end{tabular}




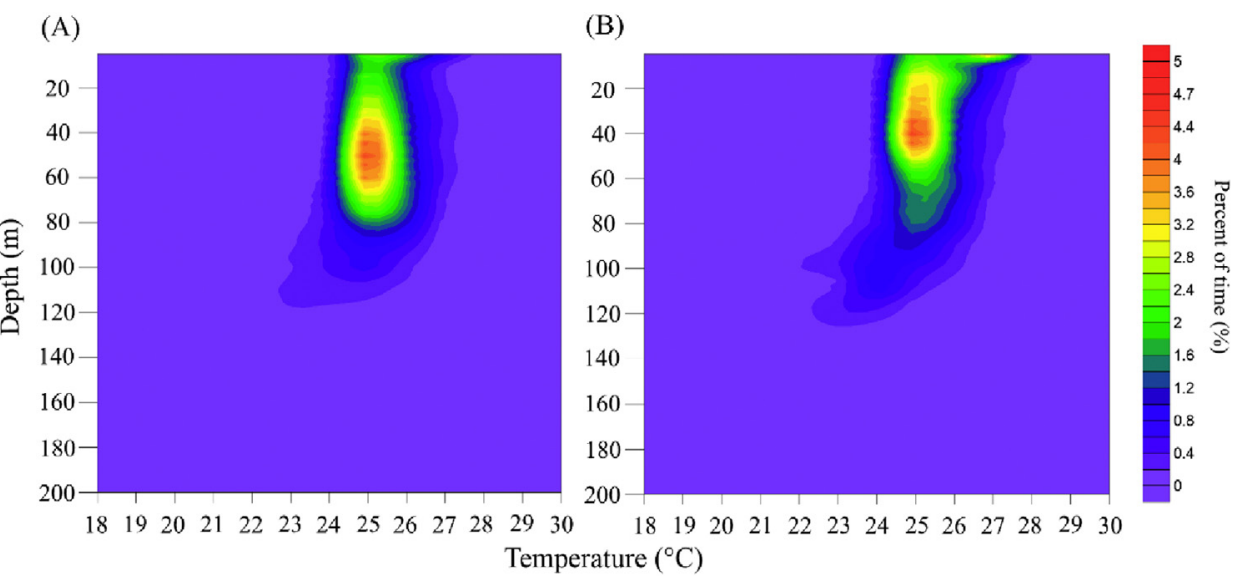

Fig. 3. Aggregated temperature-depth profiles of skipjack showing thermal preferences in daytime (A) and nighttime (B).

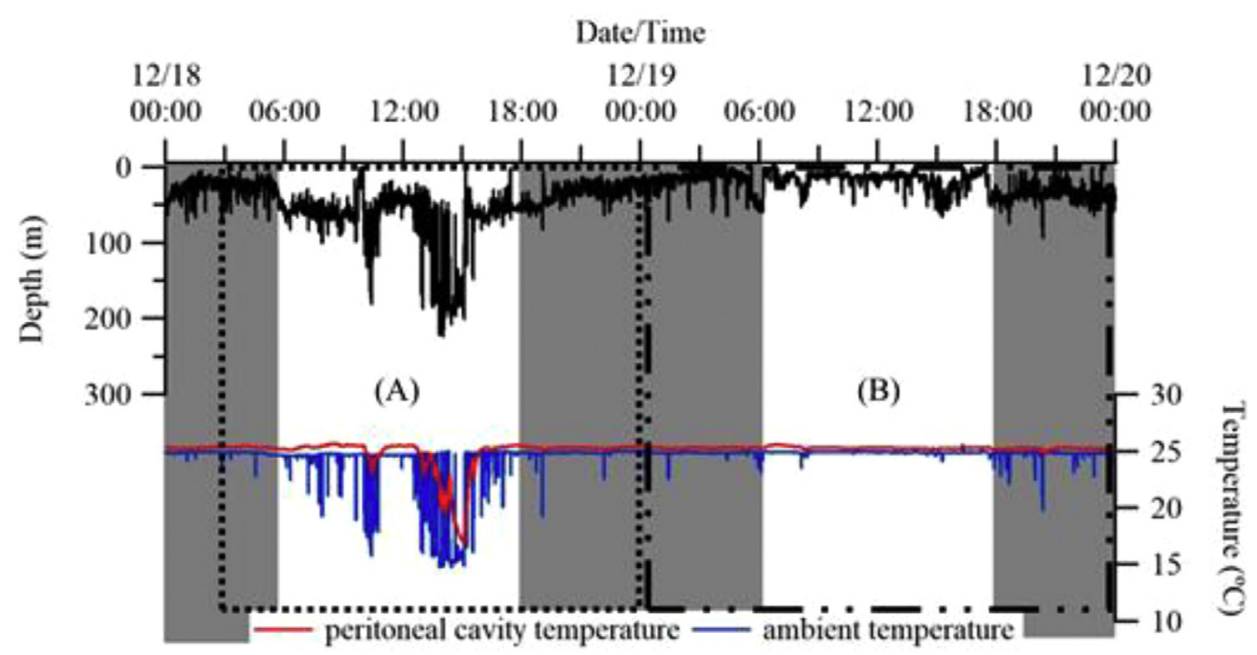

Fig. 4. Depth, peritoneal cavity and ambient temperature records for skipjack tuna (\#5885) recorded on 18-19 December 2018. (A) Skipjack showing unassociated repetitive bounce diving behavior; (B) skipjack showing associated repetitive bounce diving behavior.

showed that skipjack spent $\sim 90 \%$ of their time at temperatures with $6{ }^{\circ} \mathrm{C}$ of the warmest water available (Table 3). Three skipjack (\#7753, \#7734 and \#7729) displayed similar diving patterns with occasional deep forays whereas skipjack \#5885 and \#6312 exhibited much deeper diving patterns (Fig. 5). Skipjack \#6312 descended to $310.6 \mathrm{~m}\left(14.2{ }^{\circ} \mathrm{C}\right)$ on 30 March for $30 \mathrm{~s}$ with a peritoneal cavity

Table 3. Cumulative percentage of temperature readings from archival tags inserted to skipjack tuna in eastern Taiwan expressed as differences from daily calculated sea surface temperature $\triangle S S T\left({ }^{\circ} \mathrm{C}\right)$ by daytime and nighttime.

\begin{tabular}{|c|c|c|c|c|c|c|c|c|c|c|c|c|c|c|c|}
\hline \multirow[t]{2}{*}{ Archival tag \#ID } & \multicolumn{15}{|l|}{$\triangle \mathrm{SST}$} \\
\hline & Time & 0 & 1 & 2 & 3 & 4 & 5 & 6 & 7 & 8 & 9 & 10 & 11 & 12 & 13 \\
\hline \multirow[t]{2}{*}{$\# 5885$} & Day & 0.2 & 73.3 & 87.2 & 92.1 & 93.5 & 94.5 & 95.5 & 96.5 & 97.2 & 98.3 & 99.6 & 100 & & \\
\hline & Night & 0.8 & 86.4 & 93.5 & 96.5 & 98.9 & 99.6 & 99.7 & 99.8 & 99.9 & 99.9 & 100 & & & \\
\hline \multirow[t]{2}{*}{$\# 6312$} & Day & 0.2 & 37.9 & 59.4 & 71.8 & 78.8 & 84.7 & 89.0 & 92.7 & 95.1 & 96.9 & 98.4 & 99.2 & 99.8 & 100 \\
\hline & Night & 0.6 & 38.0 & 58.6 & 73.8 & 87.7 & 92.8 & 97.2 & 98.6 & 99.5 & 99.6 & 100 & & & \\
\hline \multirow[t]{2}{*}{ \#7753 } & Day & 0.1 & 74.2 & 95.8 & 97.6 & 99.0 & 99.5 & 99.6 & 99.7 & 99.8 & 99.9 & 100 & & & \\
\hline & Night & 0.1 & 72.0 & 99.6 & 100 & & & & & & & & & & \\
\hline \multirow[t]{2}{*}{ \#7734 } & Day & 0.1 & 85.9 & 98.5 & 99.5 & 99.7 & 99.8 & 99.9 & 100 & & & & & & \\
\hline & Night & 0.8 & 84.4 & 98.6 & 100 & & & & & & & & & & \\
\hline \multirow[t]{2}{*}{ \#7729 } & Day & 0.4 & 79.7 & 94.2 & 97.2 & 98.5 & 99.2 & 99.6 & 99.7 & 99.9 & 100 & & & & \\
\hline & Night & 0.5 & 71.7 & 95.5 & 98.8 & 99.9 & 100 & & & & & & & & \\
\hline \multirow[t]{3}{*}{ Summary } & Day & 0.2 & 70.2 & 87.0 & 91.6 & 93.9 & 95.5 & 96.7 & 97.7 & 98.0 & 98.8 & 99.3 & 99.6 & 99.8 & 100 \\
\hline & Night & 0.6 & 70.5 & 89.2 & 93.8 & 95.5 & 97.4 & 98.5 & 99.2 & 99.7 & 99.8 & 99.9 & 100 & & \\
\hline & Total & 0.4 & 70.3 & 88.1 & 92.7 & 94.5 & 96.2 & 97.2 & 98.2 & 98.6 & 99.1 & 99.6 & 99.7 & 99.9 & 100 \\
\hline
\end{tabular}



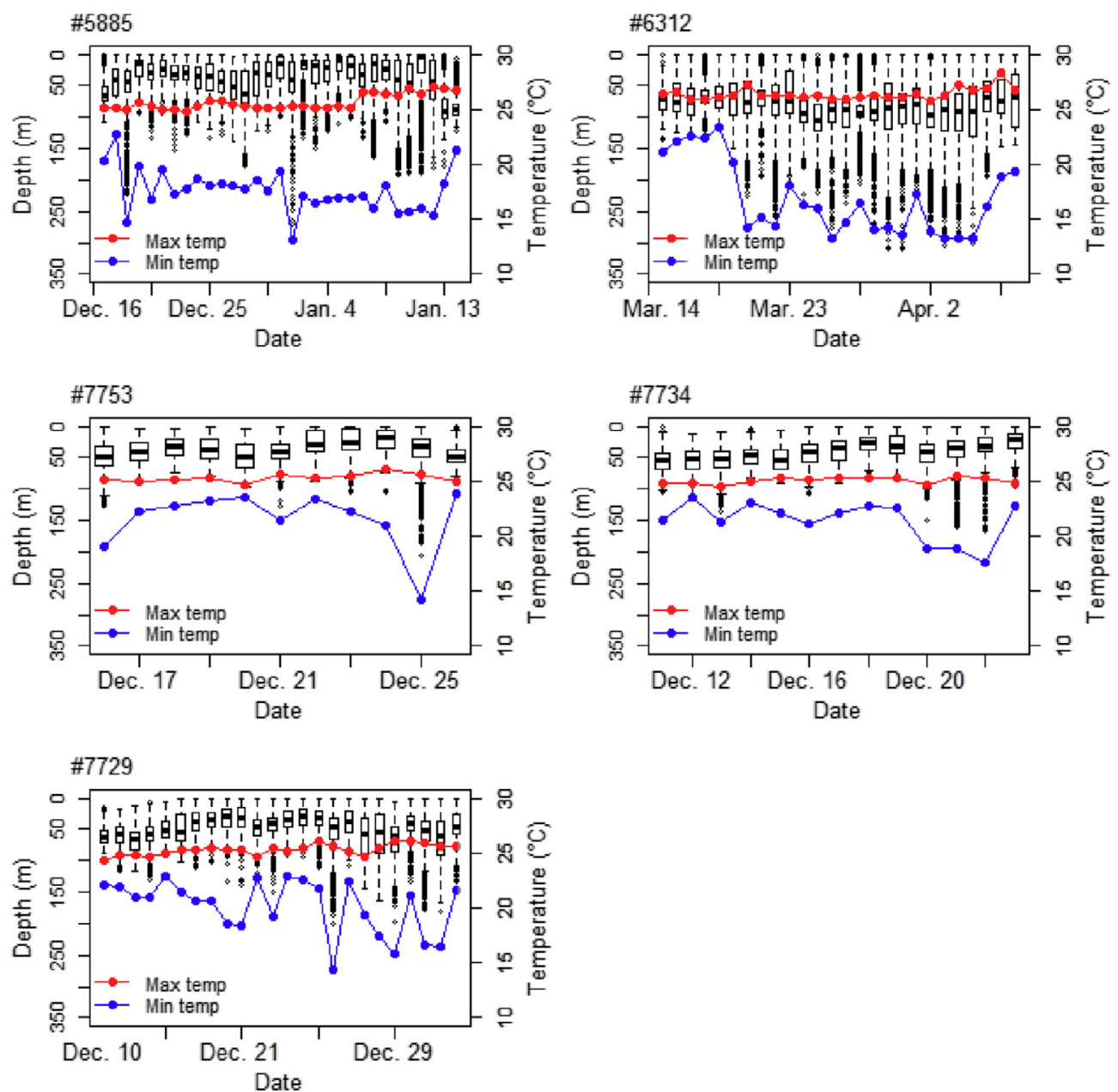

Fig. 5. Minimum and maximum daily temperature (SST) and depths experienced by tagged skipjack where boxplots represent depth. Boxes represent 95\% CI, the centerline represents the median and the bars represents maximum and minimum (dots represent outliers).

temperature of $22.3{ }^{\circ} \mathrm{C}$. Before this deep excursion, the fish was at $100 \mathrm{~m}$, then made the deep descent and returned to $100 \mathrm{~m}$ in $\sim 6$ minutes (Fig. S4). Temperature, salinity and dissolved oxygen near the study site indicated the mixed-layer was at $\sim 100 \mathrm{~m}$ at $19^{\circ}$ to $21^{\circ} \mathrm{C}$. The salinities from the surface to 200 $\mathrm{m}$ were 34.3 to $34.7 \%$, and dissolved oxygen from the surface to $150 \mathrm{~m}$ was 5.5 to $6.7 \mathrm{mg} / \mathrm{L}$, with an extended thermocline to $\sim 500 \mathrm{~m}$ at temperatures $<10^{\circ} \mathrm{C}$ with oxygen concentrations of 5.5 to $3.6 \mathrm{mg} / \mathrm{L}$ (Fig. 6).

\section{Discussion}

We recovered five immature skipjack ranging in sizes from 41-44 cm FL at release which indicated that the released skipjack probably resumed normal feeding activities after surgical implantation of the archival tag and may have exhibited schooling behavior. These fish are all about one year old [29] and are called "Hatsu Gatsuwo" which means "first and fresh bonito of the year" [13]. This is the first study to archival tag juvenile skipjack in the eastern Taiwan area to gain information on thermal habitat and behaviors around FADs. Our low tag recovery rate $(2.4 \%)$ suggests a high post-release mortality but this low rate could also be consistent with large population sizes, dispersal, tag loss or uncooperative fishers.

\subsection{Resident time around FADs}

Schaefer and Fuller [24] and Matsumoto et al. [18] indicated skipjack tuna tagged around surface FADs stayed around for only a few days and then left. However, in our study, the days at-liberty near FADs for tagged skipjack were $~ 11-31$ days, although the details about fine-scale horizontal movements were not able to be resolved with light and (or) SST based geolocations. Weng et al. [30] 


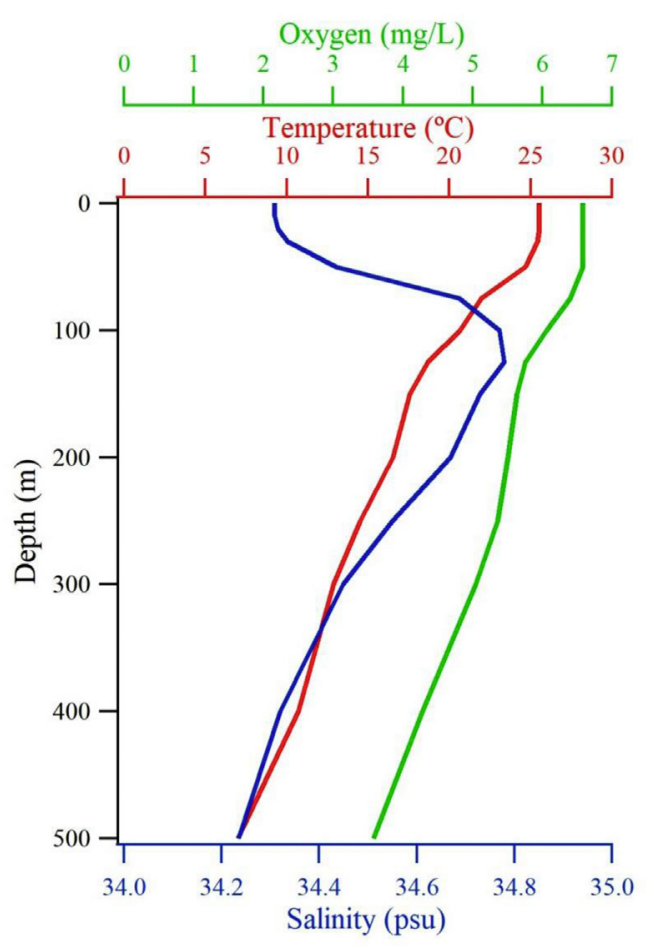

Fig. 6. Temperature, salinity and dissolve oxygen around Green Island. Data source: NOAA National Oceanographic Data Center (http://www. nodc.noaa.gov) (2018/12).

indicated juvenile yellowfin tuna stayed at subsurface FADs for $\sim 31$ days. For skipjack \#6312, the fish tagged at FAD2 and was recaptured at FAD1 (Fig. 1) after 26 days and indicated skipjack may use the FAD network for orientation and/or socialization purposes [20]. Subsurface FADs have been used to aggregate tunas off southwestern Taiwan [30,31] and fishes may stay at the FADs until the conditions are unsuitable [8].

\subsection{Vertical movements}

Schaefer and Fuller [24] defined four behavioral types for skipjack: (1) associated, (2) unassociated with floating objects, (3) deep diving behavior and (4) surface-oriented behavior. When skipjack are near floating objects, they make frequent deep dives primarily during daytime and occasionally at nighttime. Unassociated with floating objects, skipjack make significantly deeper dives diving during daytime than nighttime. Matsumoto et al. [18] also reported skipjack diving correlated with proximity to FADs with shallow diving associated near FADs and increasingly deeper dives the further away from FADs. Skipjack tuna do not possess a swim bladder [4] and during rapid directional changes whilst diving, not having to adjust for accompanying pressure changes could provide advantages to increase prey encounter rates without extensively increasing linear travel distance and expending energy [12]. As previous studies have reported, the $\mathrm{W}$-shaped movement patterns during daytime are an optimal search strategy to increase prey encounters [27] and these behaviors and physiological adaptations confer a foraging strategy for tunas [20,31,32].

\subsection{Thermal habitat}

Kiyofuji [13] discussed northward migration of skipjack tuna (size range: 38 to $51 \mathrm{~cm} \mathrm{FL)} \mathrm{in} \mathrm{the}$ western Pacific Ocean. The results indicated that skipjack tuna in the Kuroshio current did not enter water cooler than $18^{\circ} \mathrm{C}$. Our results, however, indicated that immature skipjack tuna in eastern Taiwan can visit temperatures of as low of $13.1^{\circ} \mathrm{C}$ on an ephemeral basis. The temperature preference of tagged immature skipjack (Fig. 4) were mostly between $18-28^{\circ} \mathrm{C}$ in daytime $\left(90 \%\right.$ of time above $24^{\circ} \mathrm{C}$ ) and $22-27^{\circ} \mathrm{C}$ at nighttime $\left(94 \%\right.$ of time above $\left.24^{\circ} \mathrm{C}\right)$. These findings are similar with [18] who indicated skipjack mostly stayed at $16-27^{\circ} \mathrm{C}$ in daytime and at 24-30 ${ }^{\circ} \mathrm{C}$ in nighttime and [7] provided a range of 22$30^{\circ} \mathrm{C}$. Schaefer and Fuller [24] reported adult skipjack (53-73 cm FL) stayed at temperatures from 20$26^{\circ} \mathrm{C}$ (mostly at $25^{\circ} \mathrm{C}$ ) and the deepest dive recorded was $596 \mathrm{~m}$ where the ambient temperature was $7.7^{\circ} \mathrm{C}$. Dizon et al. [9] reported temperature tolerances of $15-33^{\circ} \mathrm{C}$ based on tank experiments. The length at maturity of skipjack tuna was estimated to be about $46 \mathrm{~cm}$ FL [28] and collectively based on previous tagging studies, suggests that deeper diving is probably correlated with body size and lack of structure. The skipjack tuna in our research were young of year (YOY).

Gooding et al. [10] used captive skipjack to estimate threshold oxygen concentrations of $4.0 \mathrm{mg} / \mathrm{L}$ whereas [9] recorded skipjack swimming behavior under high $(4.1 \mathrm{mg} / \mathrm{L})$ to low oxygen $(2.1 \mathrm{mg} / \mathrm{L})$ environments that correlated with reduced swim speeds for fish 44-45 cm FL. Cayré et al. [7] monitored skipjack (41-52 cm FL) near the Comoros Archipelago and reported oxygen concentrations at 150-200 m were 3.2-3.5 mg/L. Matsumoto et al. [18] reported skipjack (36-65 cm FL) usually occupied depths less than $100 \mathrm{~m}$ with oxygen concentrations at $2.7-3.2 \mathrm{mg} / \mathrm{L}$. Therefore, it does not appear oxygen concentrations were limiting dive behavior in this study (Fig. 6).

Oxygen concentration is one of four principal factors (prey availability, temperature, hydrostatic pressure, dissolved oxygen) that restrict the 
distribution of pelagic fishes [5]. By examining the behavioral and thermal niche that define immature skipjack vertical habitat, this study provides important information to improve ecological understanding of thermal niche and provide useful data for inclusion into stock assessments.

\section{Acknowledgements}

We thank trolling FV Hong-Long No.6 captain Chen, Lian-Chun and FV Shun-Shen-Fong captain Tian, E-Shen. We also thank staff at the research center for their support in the field and fishermen at Shinkang Fishermen's Association who cooperated for tag recovery. This study was partially funded by the Fisheries Research Institute, Council of Agriculture, Taiwan (grant no. 109AS-9.2.3-AI-A5).

\section{Appendix.}

Table S1. Tagging numbers for skipjack tuna implanted with conventional tags and archival tags during 2017 to 2020.

\begin{tabular}{lllll}
\hline $\begin{array}{l}\text { Survey } \\
\text { year }\end{array}$ & $\begin{array}{l}\text { Conventional } \\
\text { tag conducted } \\
\text { number }\end{array}$ & $\begin{array}{l}\text { Archival tag } \\
\text { implanted } \\
\text { number }\end{array}$ & $\begin{array}{l}\text { Conventional } \\
\text { tag recaptured } \\
\text { number }(\%)\end{array}$ & $\begin{array}{l}\text { Archival tag } \\
\text { recaptured } \\
\text { number }(\%)\end{array}$ \\
\hline 2017 & 33 & 78 & 0 & 0 \\
2018 & 138 & 78 & 3 & 1 \\
2019 & 419 & 35 & 16 & 4 \\
2020 & 134 & 211 & $21(3 \%)$ & 0 \\
Total & 724 & & $21 \%)$ & $5(2 \%)$ \\
\hline
\end{tabular}



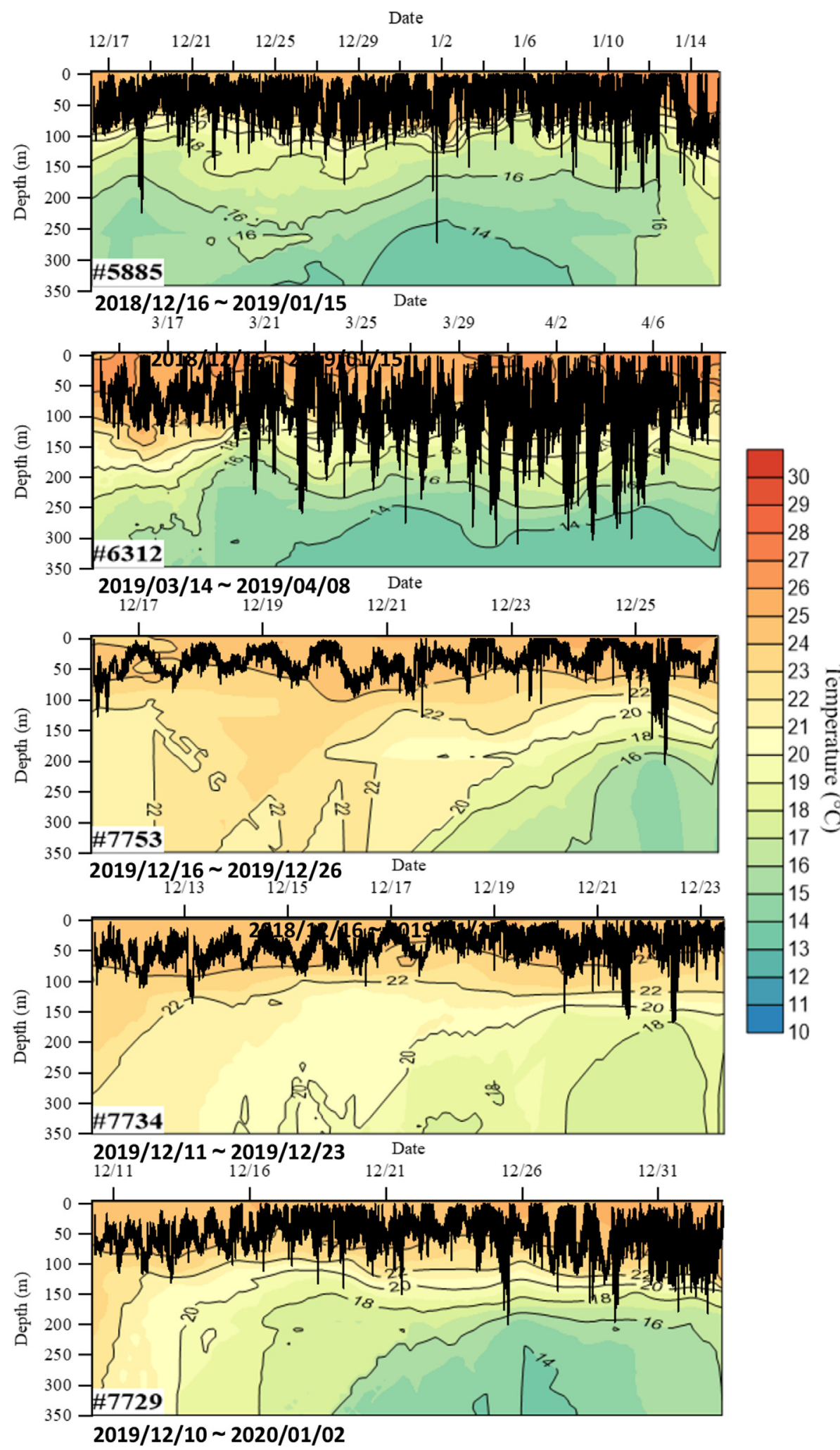

Fig. S1. Time series of depth and temperature diving patterns for tagged skipjack. 


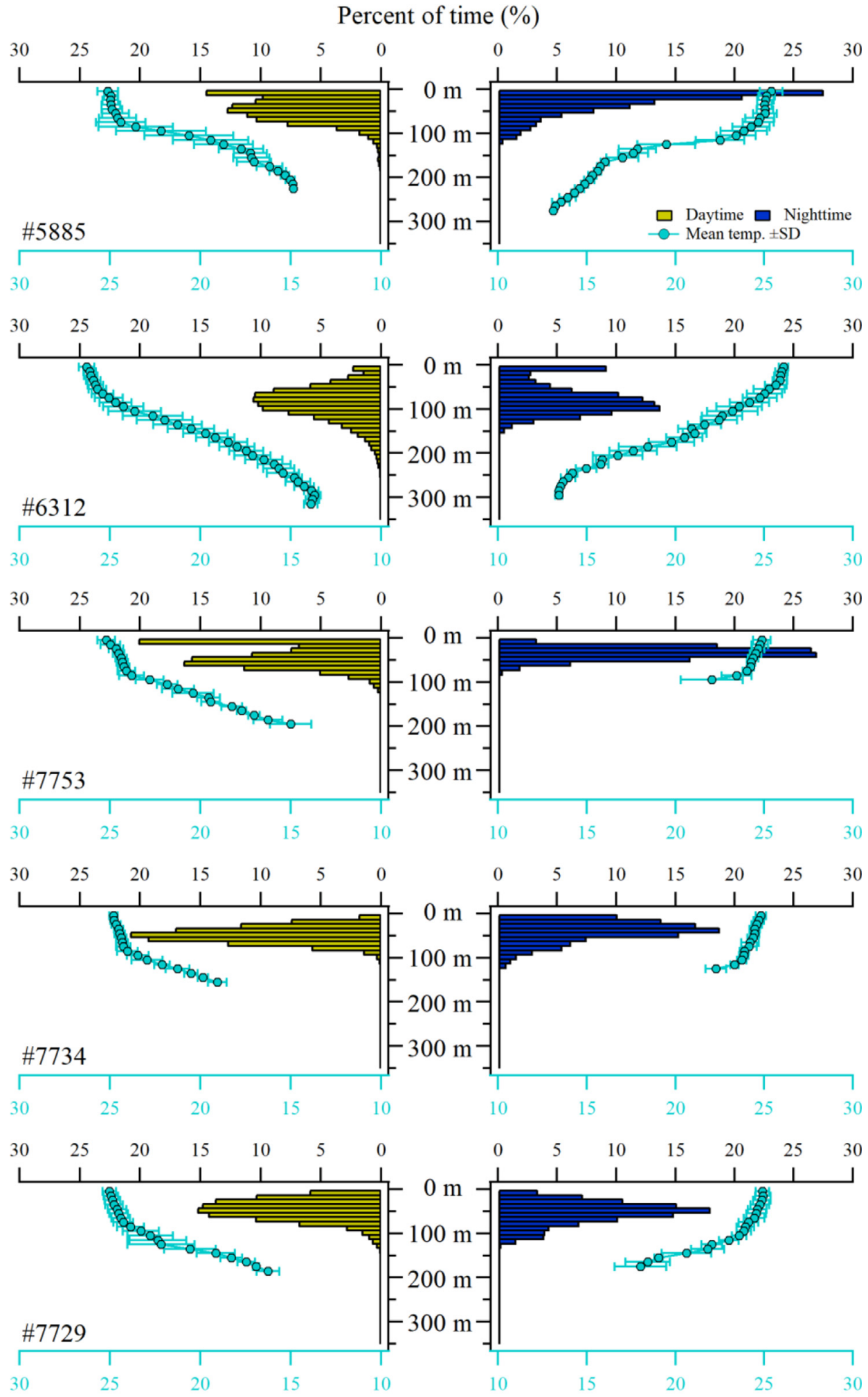

Temperature $\left({ }^{\circ} \mathrm{C}\right)$ 

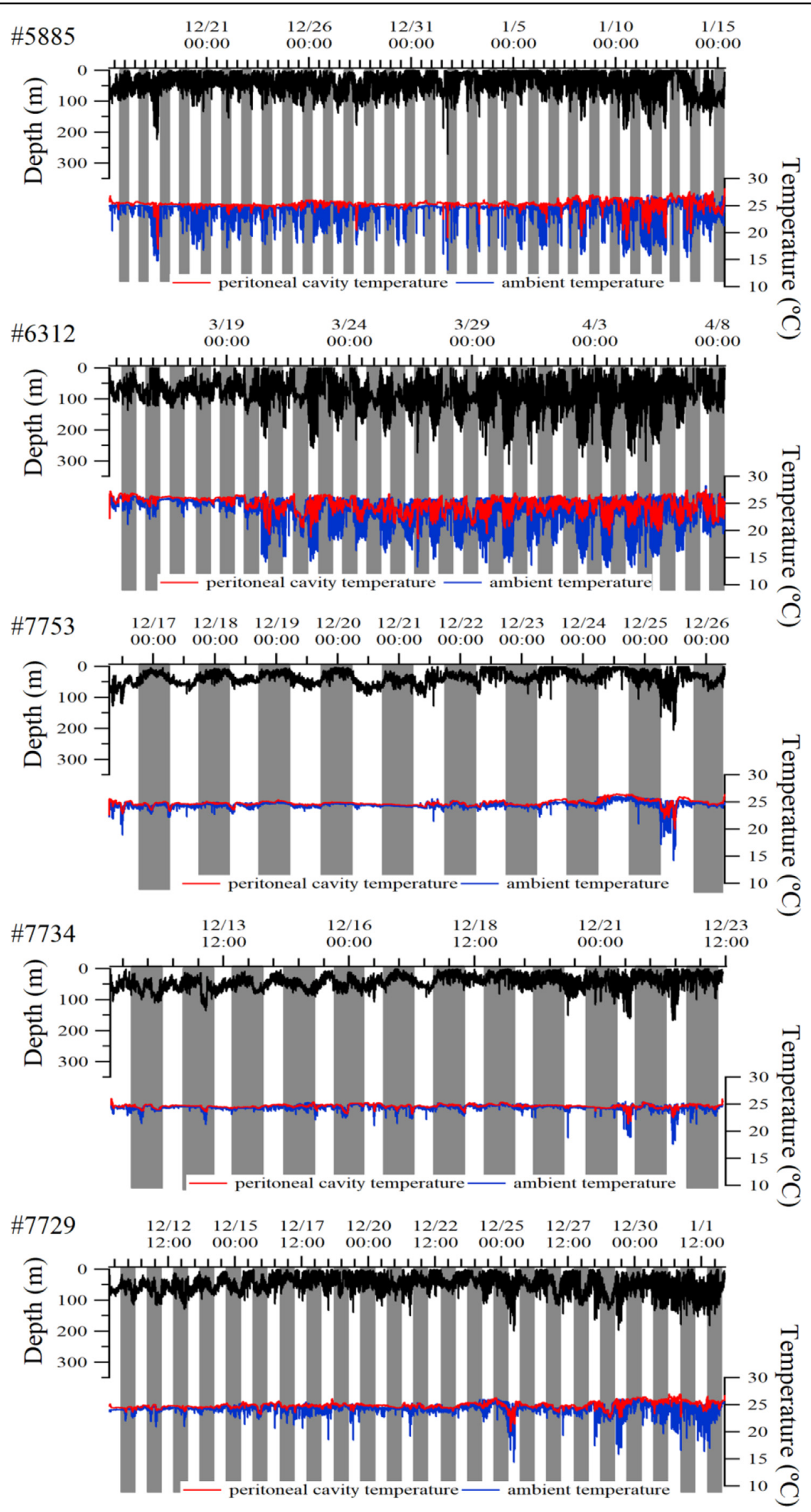

Fig. S3. Time series of depth (black), peritoneal cavity temperature (red) and ambient temperature (blue) for skipjack during daytime and nighttime (grey shading indicates nighttime). 
Time (local)
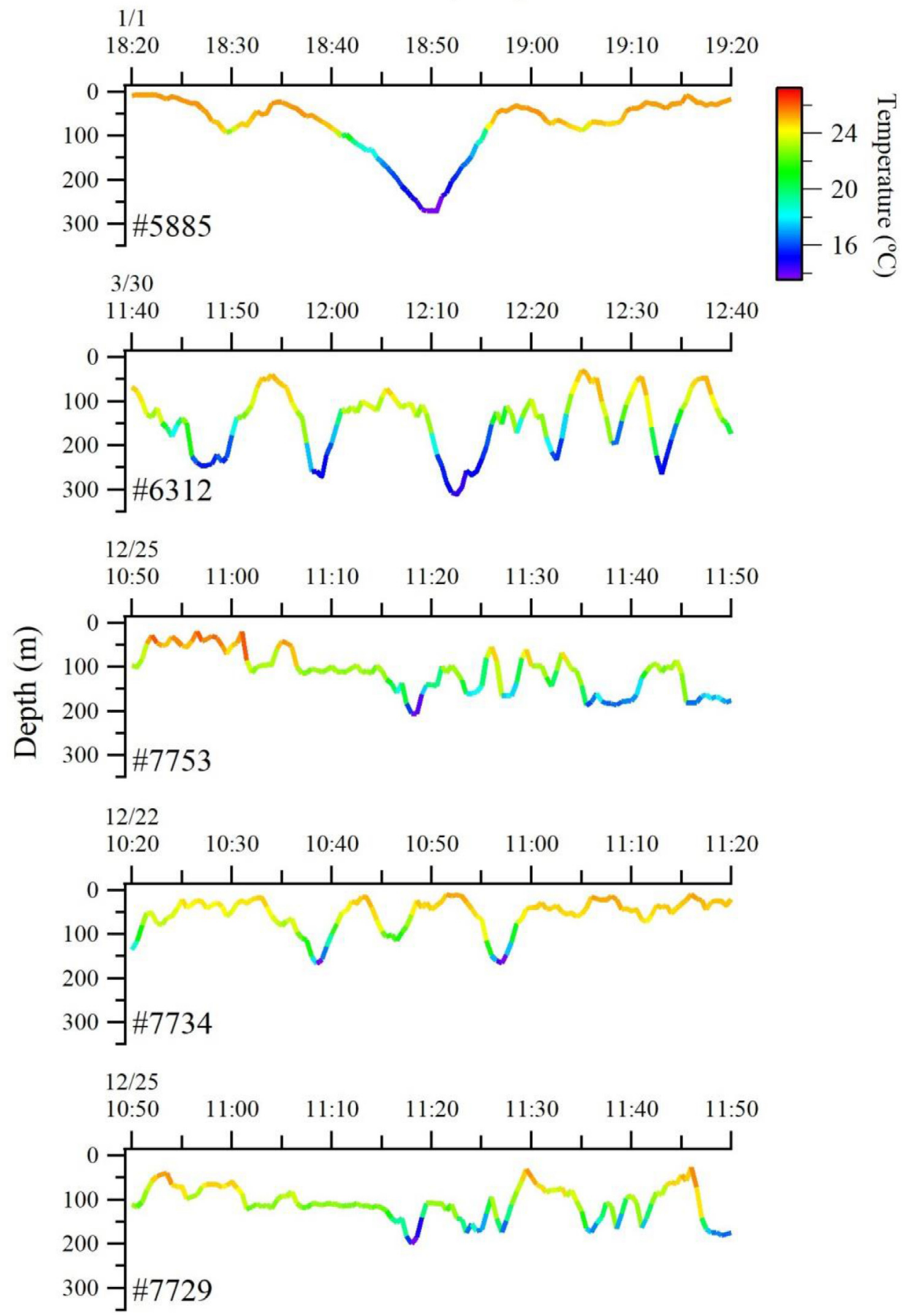

Fig. S4. Depth and temperature data by skipjack exhibiting occasional episodes of deep excursions. 


\section{References}

[1] Barkley RA, Neill WH, Gooding RM. Skipjack tuna, Katsuwonus pelamis, habitat based on temperature and oxygen requirements. In: Fishery Bulletin. 76; 1978. p. 643-61.

[2] Bauer RK, Fromentin J-M, Demarcq H, Bonhommeau S. Habitat use, vertical and horizontal behaviour of Atlantic bluefin tuna (Thunnus thynnus) in the Northwestern Mediterranean Sea in relation to oceanographic conditions. Deep Sea Res Part II: Tropical Stud Oceanogr 2017;141:248-61.

[3] Block BA, Whitlock R, Schallert RJ, Wilson S, Stokesbury MJW, Castleton M, Boustany A. Estimating natural mortality of Atlantic bluefin tuna using acoustic telemetry. Scientific Reports 2019;9:4918.

[4] Boyra G, Moreno G, Sobradillo B, Pérez-Arjona I, Sancristobal I, Demer DA, Ratilal P. Target strength of skipjack tuna (Katsuwanus pelamis) associated with fish aggregating devices (FADs). ICES J Marine Sci 2018;75:1790-802.

[5] Brill RW. A review of temperature and oxygen tolerance studies of tunas pertinent to fisheries oceanography, movement models and stock assessments. Fish Oceanogr 1994;3: 204-16.

[6] Castro JJ, Santigao JA, Santana-Ortega AT. A general theory on fish aggregation to floating object: an alternative to the meeting point hypothesis. Rev Fish Biol Fish 2002;11:255-77.

[7] Cayré P. Behavior of yellowfin tuna (Thunnus albacares) and skipjack tuna (Katsuwonus pelamis) around fish aggregating devices (FADs) in the Comoros Islands as determined by ultrasonic tagging. Aquat Living Resour 1991;4:1-12.

[8] Dagorn L, Holland KN, Itano DG. Behavior of yellowfin (Thunnus albacares) and bigeye (T. obesus) tuna in a network of fish aggregating devices (FADs). Marine Biol 2007;151: 595-606.

[9] Dizon AE, Neil WH, Magnuson JJ. Rapid temperature compensation of volitional swimming speeds and lethal temperatures in tropical tunas (Scombridae). Environ Biol Fish 1977;2:83-92.

[10] Gooding RM, Neil WH, Dizon AE. Respiration rates and low-oxygen tolerance limits in skipjack tuna, Katsuwonus pelamis. Fish Bull 1981;79:31-48.

[11] Govinden R, Jauhary R, Filmalter J, Forget F, Soria M, Adam S, Dagorn L. Movement behaviour of skipjack (Katsuwonus pelamis) and yellowfin (Thunnus albacares) tuna at anchored fish aggregating devices (FADs) in the Maldives, investigated by acoustic telemetry. Aquat Living Resour 2012;26:69-77.

[12] Horodysky AZ, Kerstetter DW, Latour RJ, Graves JS. Habitat utilization and vertical movements of white marlin (Tetrapturus albidus) released from commercial and recreational fishing gears in the western North Atlantic Ocean: inferences from short duration pop-up archival satellite tags. Fish Oceanogr 2007;16:240-56.

[13] Kiyofuji H, Aoki Y, Kinoshita J, Okamoto S, Masujima M, Matsumoto T, Fujioka K, Ogata R, Nakao T, Sugimoto N, Kitagawa T. Northward migration dynamics of skipjack tuna (Katsuwonus pelamis) associated with the lower thermal limit in the western Pacific Ocean. Prog Oceanogr 2019;175:55-67.

[14] Lehodey P, Bertignac M, Hampton J, Lewis A, Picaut J. El Niño Southern Oscillation and tuna in the western Pacific. Nature 1997;389:715-8.

[15] Lehodey P, Senina I, Murtugudde R. A spatial ecosystem and populations dynamics model (SEAPODYM)-Modeling of tuna and tuna-like populations. Progress in Oceanography 2008;78:304-18.

[16] Marsac F, Cayre P. Telemetry applied to behaviour analysis of yellowfin tuna (Thunnus albacares, Bonnaterre, 1788) movements in a network of fish aggregating devices. Hydrobiologia 1998;371/372:155-71.

[17] Matsumoto T, Kitagawa T, Kimura S. Vertical behavior of bigeye tuna (Thunnus obesus) in the northwestern Pacific
Ocean based on archival tag data. Fish Oceanogr 2013;22: 234-46.

[18] Matsumoto T, Satoh K, Toyonaga M. Behavior of skipjack tuna (Katsuwonus pelamis) associated with a drifting FAD monitored with ultrasonic transmitters in the equatorial central Pacific Ocean. Fish Res 2014;157:78-85.

[19] Matsumoto WM, Skippman RA, Dizon AE. Synopsis of biological data on skipjack tuna, Katsuwonus pelamis. 1984 NOAA Technical Report NMFS Circular.

[20] Musyl MK, Brill RW, Boggs CH, Curran DS, Kazama TK, Seki MP. Vertical movements of bigeye tuna (Thunnus obesus) associated with islands, buoys, and seamounts near the main Hawaiian Islands from archival tagging data. Fish Oceanogr 2003;12:152-69.

[21] Orue B, Lopez J, Moreno G, Santiago J, Soto M, Murua H. Aggregation process of drifting fish aggregating devices (DFADs) in the Western Indian Ocean: Who arrives first, tuna or non-tuna species? PLoS ONE 2019;14:e0210435.

[22] Schaefer KM, Fuller DW. Movements, behavior, and habitat selection of bigeye tuna (Thunnus obesus) in the eastern equatorial Pacific, ascertained through archival tags. In: Fishery Bullettin. 100; 2002. p. 765-88.

[23] Schaefer KM, Fuller DW. Behavior of bigeye (Thunnus obesus) and skipjack (Katsuwonus pelamis) tunas within aggregations asso-ciated with floating objects in the equatorial eastern Pacific. Marine Biol 2005;146:781-92.

[24] Schaefer KM, Fuller DW. Vertical movement patterns of skipjack tuna (Katsuwonus pelamis) in the eastern equatorial Pacific Ocean, as revealed with archival tags. In: Fishery Bulletin. 105; 2007. p. 379-89.

[25] Schaefer KM, Fuller DW, Block BA. Movements, behavior, and habitat utilization of yellowfin tuna (Thunnus albacares) in the Pacific Ocean off Baja California, Mexico, determined from archival tag data analyses, including unscented Kalman filtering. Fish Res 2011;112:22-37.

[26] Senina I, Sibert J, Lehodey P. Parameter estimation for basinscale ecosystem-linked population models of large pelagic predators: Application to skipjack tuna. Prog Oceanogr 2008; 78:319-35.

[27] Sims DW, Southall EJ, Humphries NE, Hays GC, Bradshaw CJA, Pitchford JW, James A, Hindell MA, Morritt D, Musyl MK, Righton D, Shepard ELC, Wearmouth VJ, Wilson RP, Witt MJ, Metcalfe JD. Scaling laws of marine predator search behaviour. Nature 2008;451:1098-102.

[28] Soares BJ, Monteiro-Neto C, Costa MRd, Martins RRM, Vieira FCdS, Andrade-Tubino MFd, Bastos AL, Tubino RdA. Size structure, reproduction, and growth of skipjack tuna (Katsuwonus pelamis) caught by the pole-and-line fleet in the southwest Atlantic. Fish Res 2019;212:136-45.

[29] Tanabe T, Kayama S, Ogura T. Precise age determination of young to adult skipjack tuna (Katsuwonus pelamis) with validation of otolith daily increment. In: 16th Meeting of the Standing Committee on Tuna and Billfish (SCTB16); 2003. p. 1-10. Working Paper.

[30] Weng JS, Hung MK, Lai CC, Wu LJ, Lee MA, Liu KM. Finescale vertical and horizontal movements of juvenile yellowfin tuna (Thunnus albacares) associated with a subsurface fish aggregating device (FAD) off southwestern Taiwan. J Appl Ichthyol 2013;29:990-1000.

[31] Weng JS, Lee MA, Liu KM, Huang HH, Wu LJ. Habitat and behaviour of adult yellowfin tuna (Thunnus albacares) in the waters off southwestern Taiwan determined by pop-up satellite archival tags. Aquat Living Resour 2017;30.

[32] Weng KC, Stokesbury MJW, Boustany AM, Seitz AC, Teo SLH, Miller SK, Block BA. Habitat and behaviour of yellowfin tuna Thunnus albacares in the Gulf of Mexico determined using pop-up satellite archival tags. J Fish Biol 2009. 74:1434-49.

[33] Zar JH. Biostatistical Analysis. 5th. New Jersey: Prentice Hall; 2010. 